\title{
Hematological parameters that determine the course of labor and the postpartum period in highly productive Holstein cows
}

\author{
Murat Baimishev ${ }^{1}$, Rinat Baimishev ${ }^{1}$, Sergei Eremin ${ }^{2}$ and Hamidulla Baimishev ${ }^{1, *}$ \\ ${ }^{1}$ Samara State Agrarian University, Kinel, Samara region 446442, Russia \\ ${ }^{2}$ Nizhny Novgorod Agricultural Academy, Nizhny Novgorod 603107, Russia
}

\begin{abstract}
The aim of the study is to determine the effect of hematological parameters of cows on the course of labor and the postpartum period in highly productive Holstein cows. For this purpose, one group of cows was formed on the principle of analogue pairs in the amount of 30 animals with a gestation period of 7.58.0 months, followed by blood sampling from them using the Monovet system in vacuum test tubescontainers to determine morphological and biochemical parameters. Blood was taken 25-30 days before delivery in the morning 2 hours before feeding. Blood values were studied according to generally accepted methods using certified equipment. Subsequently, depending on the nature of the course of the birth, the animals were divided into two groups. The first group included 24 cows without pathology of the course of labor and the postpartum period, the second group included 16 cows with pathologies of the course of labor and the postpartum period. In the process of research, it was found that in $60.0 \%$ of the cows the birth and the postpartum period passed without pathologies, and in $40.0 \%$ of the birth and postpartum complications were revealed (retention of the placenta, acute postpartum endometritis, uterine subinvolution). A comparative analysis of the blood values of cows 25-30 days before birth the course of the labor process and postpartum period showed that in animals without pathology - compared to the animals with pathologies - the hematological parameters are considerably higher (hemoglobin content by $16.42 \mathrm{~g} / \mathrm{l}$, total protein by $10.96 \mathrm{~g} / \mathrm{l}$, albumin by $7.7 \%$, calcium by $0.98 \mathrm{mmol} / \mathrm{l}$, glucose by $0.91 \mathrm{mmol}$, immunoglobin A by $59.77 \mathrm{mg} / \mathrm{M}$ ), while the content of beta-globulins is lower by $8.51 \%$ and that of enzyme AcT is lower by 25.94 units/l. A decrease in blood biochemical parameters contributes to the manifestation of the pathology of labor and the postpartum period. The data obtained can be used to develop an algorithm for the prevention of postpartum complications in highly productive cows.
\end{abstract}

\section{Introduction}

Dairy farming plays a major role in providing the country with high-quality environmentally friendly products. However, one of the main constraining factors for its development are frequent obstetric and gynecological diseases of animals involved in active production of milk of [1-4].

Hematological parameters are one of the main informative systems, and since ancient times have been attracting the attention of researchers. These indicators are the main ones both in determining the normal state of an animal and in indicating the presence of pathological processes in the body. The dynamics of these changes differs significantly depending on the nature of the pathology and physiological state of the animal, which may be a consequence of the particular reaction of the body to the manifestation of the response [5-8].

The morphological composition of the blood of pregnant animals is characterized by mobile equilibrium and is very sensitive to the effects of external and internal stimuli. In the second half of pregnancy, the content of leukocytes and erythrocytes in blood increases in cows, and during labor it reaches a maximum [9-12].
A number of researchers note that in highly productive cows, the level of hemoglobin, erythrocytes, alkaline reserve, carotene, immunoglobulins is reduced before and after labor, which is associated with fetal growth [13-15].

According to O. V. Kremnev [6], a decrease in blood levels of total protein, albumin fraction, alpha globulin, alkaline reserve by $11.0-18.5 \%$ is a consequence of prolonged lactation in highly productive cows.

The study of biochemical blood parameters of cows in the dynamics of pregnancy and in the postpartum period in normal and obstetric pathology is the result of metabolic disorders. By determining the role of protein, lipid, and mineral metabolism in the genesis of postpartum pathology, it was found that their decrease at the end of pregnancy indicates the predominance of anabolic processes in the body of cows during this period. During pregnancy, significant changes in the blood system and cardiovascular system occur in the body of cows. It is precisely on their functional activity that the fetus is provided with oxygen and nutrients and the biochemical status of the blood of cows before childbirth, and consequently, the rate of birth and the birth of a viable offspring $[3,16,17]$. 
The course of labor and the postpartum period in cows is accompanied by a significant change in the activity of all body systems, which is associated with the need to create "comfortable" conditions for the fetus, involution of the genitals, ensuring the health of the fetus and the mother's body, as well as obtaining high-quality products in the future. The most significant changes in the course of the labor and postpartum period occur in the blood system and cardiovascular system. Providing the body of mother cows with oxygen and nutrients depends on their functional activity, normalizing the morphofunctional state of the animal. Blood values during this period depend on the functional activity of the mother-placenta-fetus system. A defect in the placentation leads to a violation of the uteroplacental circulation, which causes a complication of the course of labor and the postpartum period $[6,10,16]$.

The relationship between morphobiochemical blood parameters of pregnant cows before labor, during labor and in the postpartum period is understudied. In the literature there is limited information about blood counts in postpartum pathology. In this connection, the study of morphobiochemical blood gradient of cows before birth and their effect on the course of labor and the postpartum period is relevant.

The purpose of the work is to determine the effect of blood indicators of cows on the course of labor and the postpartum period. The following tasks were set:

- to study the morphological parameters of blood of cows 25-30 days before birth;

- to analyze blood indicators in cows, taking into account the course of labor.

\section{Materials and Methods}

The material for the study was blood obtained from cows of the Holstein breed kept in the dairy complex of the State Unitary Enterprise Kupinsky. For this, according to the method of pair-analogues, a group of cows was formed in the amount of 30 animals after the first lactation with an average milk production of $8300 \mathrm{~kg}$ and a live weight of $527 \mathrm{~kg}$. The formation of a group of animals was carried out taking into account their physiological state in the second half of pregnancy 25-30 days before calving. For this, we used the data of zootechnical registration and the results of an ultrasound study on pregnancy using the KAIXIN-5200 VET device.

In the process of research, all animals were in the same conditions of feeding and keeping (cubicle system). To determine the morphophysiological state of cows, blood was taken from all animals 25-30 days before calving. Blood was taken from the tail vein using the Monovet closed system at the same time of the day 2 hours before feeding in 2 containers: one for serum and the other with the addition of heparin for analysis with whole blood.

Morphobiochemical, immunological parameters of blood and its serum were studied with the following indicators: hemoglobin by hemoglobin-cyanide method (Drabkin) using ready-made kits; erythrocytes according to the method of Vorobyov; white blood cells in the counting chamber of Goryaev; total serum protein by refractometric method; protein fractions according to the method of K.I. Wurgaft; glucose by enzymatic colorimetric method using ready-made sets "Vital"; A, $\mathrm{M}, \mathrm{G}$ immunoglobulins using an acoustic analyzer AKBa-01 "Biom"; the concentration of total calcium in serum was determined complexometrically; inorganic phosphorus level according to the Raevsky method; serum content of the enzymes Alt and AcT was determined by the method of kinetic analysis (JFCC). Immunobiological blood values were determined on a certified Hitachi equipment (Japan) in the hematology laboratory of Samara State Medical University.

Reproductive indicators of the studied group of cows were studied by the following indicators: the course of labor and the postpartum period, the manifestation of postpartum complications. According to the results of the labor and the postpartum period, the studied group of cows was divided into 2 groups: the first included animals in which labor and the postpartum period proceeded without pathology; the second group included animals in which there was a violation of the course of labor and the postpartum period. Subsequently, an analysis was made of the blood indices of the studied groups of cows, depending on the nature of the course of labor and the postpartum period to determine which blood counts and gradients of their parameters provide the norm for the course of labor and the postpartum period in cows. Using these methods allowed solving the problems posed in the work.

The digital material of the obtained data was processed by the method of variation statistics for the significance of differences in the compared indicators using Student's criteria adopted in biology and veterinary medicine using the Microsoft Excel 7 software package. The degree of reliability of the processed data is reflected by the corresponding notation: $\mathrm{P}<0.05 *$; $\mathrm{P}<0.01 * * ; \mathrm{P}<0.001 * * *$.

\section{Results}

The studies of the blood of cows 25-30 days before calving and the degree of their influence on the course of labor and the postpartum period have shown that the blood counts of cows determine the nature of manifestation of birth and postpartum pathologies (Table 1).

Table 1. Course of labor and the postpartum period for cows

\begin{tabular}{|l|c|c|}
\hline \multirow{2}{*}{ Indicators } & \multicolumn{2}{|c|}{ Groups of animals } \\
\cline { 2 - 3 } & $\begin{array}{c}\text { norm } \mathbf{6 0} \% \\
\text { of cows })\end{array}$ & $\begin{array}{c}\text { pathology } \\
\mathbf{( 4 0 \%} \% \mathbf{~ o f ~ c o w s )}\end{array}$ \\
\hline Duration of labor, h & $8.50 \pm 1.20$ & $12.40 \pm 1.75$ \\
\hline $\begin{array}{l}\text { including separation } \\
\text { of the placenta }\end{array}$ & $3.12 \pm 0.56$ & $7.83 \pm 0.70$ \\
\hline $\begin{array}{l}\text { End of uterine } \\
\text { involution, days }\end{array}$ & $28.57 \pm 1.48$ & $57.56 \pm 3.22$ \\
\hline $\begin{array}{l}\text { Birth and postpartum } \\
\text { complications, \%: }\end{array}$ & - & 10.00 \\
\hline $\begin{array}{l}\text { retention of the } \\
\text { afterbirth }\end{array}$ & - & 20.00 \\
\hline $\begin{array}{l}\text { acute postpartum } \\
\text { endometritis }\end{array}$ & - & 50.00 \\
\hline uterine subinvolution & & \\
\hline
\end{tabular}


Out of 30 cows, the normal course of labor and the postpartum period was observed in 18 animals $(60.00 \%)$. During the course of calving and the postpartum period, pathologies were found in 12 animals $(40.00 \%)$. The duration of labor for cows without pathology was $8.50 \pm 1.20$ hours, which is 3.9 hours less than in cows with pathology. The main pathology during labor for cows is retention of the placenta. The duration of separation of the placenta for cows with pathology was $7.83 \pm 0.70$ hours, which is 4.71 hours more than for cows with a normal course of labor. Retention of the placenta for cows with a pathology of calving was $10.00 \%$, and postpartum complications in cows with a pathology of the course of labor were manifested in the form of acute postpartum endometritis in $20.00 \%$ and uterine subinvolution in $50.00 \%$. Postpartum pathologies also influenced the duration of uterine involution. In cows without pathology, it ended by 28.75 days, and by 57.5 days in cows with pathology which is 28.99 days more (more than 2 times).

Table 2. Indicators of blood and its serum in the studied groups of cows

\begin{tabular}{|c|c|c|c|}
\hline \multirow[b]{2}{*}{ Indicators } & \multirow{2}{*}{$\begin{array}{c}25-30 \text { days } \\
\text { before calving }\end{array}$} & \multicolumn{2}{|c|}{ Groups of animals } \\
\hline & & no pathologies & \begin{tabular}{|c} 
with \\
pathologies
\end{tabular} \\
\hline Hemoglobin [g /l] & $101.12 \pm 3.40$ & $109.22 \pm 2.96^{\text {** }}$ & $92.80 \pm 2.79$ \\
\hline $\begin{array}{l}\text { White blood } \\
\text { cells }\left[10^{9} / 1\right]\end{array}$ & $8.43 \pm 2.04$ & $8.12 \pm 0.34$ & $9.04 \pm 0.46$ \\
\hline $\begin{array}{c}\text { Erythrocytes } \\
{\left[10^{12} / 1\right]}\end{array}$ & $5.01 \pm 0.77$ & $5.33 \pm 0.21^{*}$ & $3.82 \pm 0.27$ \\
\hline $\begin{array}{c}\text { Total protein } \\
{[\mathrm{g} / \mathrm{l}]}\end{array}$ & $62.18 \pm 4.78$ & $73.14 \pm 2.12^{* *}$ & $57.17 \pm 2.16$ \\
\hline Albumin [\%] & $40.18 \pm 3.05$ & $44.13 \pm 0.84^{* *}$ & $36.43 \pm 1.12$ \\
\hline $\begin{array}{l}\text { Globulins [\%], } \\
\text { including }\end{array}$ & $59.82 \pm 4.18$ & $55.87 \pm 0.78^{*}$ & $63.57 \pm 2.04$ \\
\hline Alpha globulins & $14.67 \pm 0.36$ & $16.79 \pm 0.27^{* * *}$ & $12.40 \pm 0.35$ \\
\hline Beta globulins & $17.32 \pm 0.17$ & $13.64 \pm 0.14$ & $22.10 \pm 0.48^{* * * *}$ \\
\hline $\begin{array}{c}\text { Gamma } \\
\text { globulins }\end{array}$ & $27.83 \pm 0.88$ & $25.44 \pm 0.55^{*}$ & $28.93 \pm 0.70$ \\
\hline $\begin{array}{l}\text { Total protein } \\
{[\mathrm{mmol} / \mathrm{l}]}\end{array}$ & $1.92 \pm 0.12$ & $2.76 \pm 0.06^{*}$ & $1.78 \pm 0.08$ \\
\hline $\begin{array}{c}\text { Inorganic } \\
\text { phosphorus } \\
{[\mathrm{mmol} / \mathrm{l}]} \\
\end{array}$ & $1.27 \pm 0.10$ & $1.51 \pm 0.11$ & $1.07 \pm 0.09$ \\
\hline $\begin{array}{c}\text { Alkaline reserve } \\
{\left[\text { vol. } \% \mathrm{CO}_{2}\right]}\end{array}$ & $42.11 \pm 4.05$ & $48.13 \pm 2.27^{* *}$ & $38.85 \pm 1.76$ \\
\hline Glucose [mmol/l] & $2.13 \pm 0.27$ & $2.79 \pm 0.05^{*}$ & $1.88 \pm 0.08$ \\
\hline Carotene [mg \%] & $0.42 \pm 0.24$ & $0.58 \pm 0.07$ & $0.29 \pm 0.04$ \\
\hline \multicolumn{4}{|l|}{$\begin{array}{c}\text { Immunoglobulins } \\
{[\mathrm{mg} / \mathrm{dl}]}\end{array}$} \\
\hline $\mathrm{A}$ & $148.54 \pm 9.80$ & $186.40 \pm 7.13^{* * * *}$ & $126.63 \pm 5.81$ \\
\hline $\mathrm{M}$ & $108.32 \pm 5.14$ & $127.31 \pm 2.18^{* * * *}$ & $97.16 \pm 2.45$ \\
\hline $\mathrm{G}$ & $1089.85 \pm 25.63$ & $1187.15 \pm 18.42^{* *}$ & $1012.77 \pm 14.17$ \\
\hline GOT[units/l] & $96.20 \pm 7.18$ & $78.55 \pm 4.16^{* * * *}$ & $104.49 \pm 3.58^{* * * *}$ \\
\hline GPT [units/l] & $115.00 \pm 9.20$ & $101.16 \pm 2.92$ & $124.29 \pm 7.12^{* * *}$ \\
\hline
\end{tabular}

In a comparative analysis, it was found that blood counts for 25-30 days before birth in cows, depending on the nature of the course of labor and the postpartum period, are not the same. The hemoglobin content in cows with pathology was significantly $(\mathrm{P}<0.01)$ less by $16.42 \mathrm{~g} / \mathrm{l}$, and that of erythrocytes less by $1.5110^{12} / \mathrm{l}$, than in the group of cows without pathology. The amount of total protein on average in all cows 25-30 days before calving was $62.18 \mathrm{~g} / \mathrm{l}$; for cows without pathologies this indicator increased by $10.96 \mathrm{~g} / \mathrm{l}$, and for cows with pathologies it decreased to $57.17 \mathrm{~g} / \mathrm{l}$.The content of protein fractions (albumin, globulin) has its own specificity. The percentage of albumin in cows with pathology was $36.43 \%$, which is $7.70 \%$ less than in cows without pathology and $3.95 \mathrm{~g} / 1$ less than the average in cows 25-30 days before calving. Of particular interest is an increase of $8.64 \%$ of betaglobulins in animals with pathology, which is a symptom of the manifestation of pathology. An increase in the content of gamma globulins indicates the presence of pathological processes in the body of cows, which is associated with their immunoprotective function (Table 2).

The calcium content in cows with pathology is 0.98 mmol less compared to the group of cows without pathology; the difference is significant $\mathrm{P}<0.05$. The amount of phosphorus in the blood serum of nonpathological cows was $1.51 \pm 0.11 \mathrm{mmol} / \mathrm{l}$, which is 0.44 $\mathrm{mmol} / \mathrm{l}$ less. The serum alkaline reserve in cows of the first group (without pathology) was 9.28vol. \% CO2 more and amounted to $48.13 \pm 2.27$ vol. \% $\mathrm{CO} 2$ compared with cows of the second group (with pathology). The glucose and carotene content in the cows of the first group is $0.91 \mathrm{mmol} / 1$ and $0.25 \mathrm{mg} \%$ higher than these indicators in the cows of the second group. In the blood serum of cows-groups without pathologies - the content of immunoglobulins (A $59.77 \mathrm{mg} / \mathrm{dl}, \mathrm{M}-30.15 \mathrm{mg} / \mathrm{dl}, \mathrm{G}-174.38 \mathrm{mg} / \mathrm{dl}$ )was significantly more than cows of the pathology group. The serum content of the GOT and GPT in cows of the first group was 25.94 and 23.13 units/1 less than in cows without pathology and corresponds to the reference value, while these indicators in cows of the second group exceed them.

\section{Discussion}

In a group of cows with pathology of labor and the postpartum period, 25-30 days before calving, the content of immunoglobulins A, M, G in the blood serum was $32.0,2.3$ and $14.6 \%$, respectively, less than in cows with no labor and postpartum complications. The data obtained are consistent with the studies of M.A. Bagmanov and R.N. Mukhmetgaliev [9] that a decrease in the immune status indicator before labor causes postpartum complications. A decrease in immunobiological parameters in the prenatal period enhances the pathogenicity of conditionally pathogenic microflora which, penetrating the genitals of animals, causes inflammatory processes $[18,7]$.

According to the research results, one can agree with the opinion of A. G. Nezhdanov [8] who believes that in the prenatal period the animal organism undergoes morphophysiological stress, which is associated with an increase in the consumption of energy material, which is expressed by a change in the mineral composition of cell structures and blood serum. In the blood serum 25-30 days before the birth, the group of cows with 
pathology of the birth and postpartum period had a lesser calcium content by $0.98 \mathrm{mmol} / \mathrm{L}$, glucose content by $0.91 \mathrm{mmol}$ and phosphorus content by $0.44 \mathrm{mmol} / \mathrm{L}$.

The alkaline reserve of blood in cows without pathology was 9.28 vol. \% $\mathrm{CO}_{2}$ more than in cows with the manifestation of labor and postpartum complications and amounted to 48.13 vol. \% $\mathrm{CO}_{2}$. The decrease in reserve alkalinity in cows with pathology indicates a shift in the acid-base balance towards acidosis. Under the conditions of industrial technology, metabolic acidosis is noted with the same type of high-concentrate feeding and violation of the technology of feeding dry cows, which leads to a violation of the reproductive function of cows $[1,2,19]$. The data obtained in the research process on the indicators of the alkaline reserve in the blood serum of cows for 25-30 days indicate that a decrease in this indicator to 38.85 vol. $\% \mathrm{CO}_{2}$ is predisposing factors for the manifestation of birth and postpartum complications.

Hypoglycemia - a decrease in blood glucose - is observed in animals with prolonged functional load on the body, pancreatic hypertrophy, liver damage, ketosis. In ruminants, carbohydrate metabolism plays a significant role in determining the level of intensity of other types of metabolism. The main indicator of carbohydrate metabolism is the concentration of glucose in the blood, which remains constant when it is continuously extracted from the blood during the metabolism, which causes absorption from the digestive tract by glycogenolysis and glucoginesis. Violation of the dynamic balance of glucose is possible provided that the tissue needs for it increase under stress should be accompanied by an increase in its entry into the blood. A decrease in glucose is a symptom of a serious disruption in glycogen stores in the liver and muscles. Muscle glucose deficiency has a negative effect on the contractility of the uterine myometrium $[9,18,12]$.

According to S.A. Chulichkova [6], a decrease in the glucose content in the blood serum of cows increases the period of uterine involution and leads to the occurrence of postpartum endometritis, and a decrease in the calcium index causes a weakening of the uterine contractility, which is associated with longer delivery in cows with a pathology of 3.9 hours and the manifestation of half-period pathologies in the form of retention of the placenta $(10.0 \%)$, uterine subinvolution $(50.0 \%)$ and postpartum endometritis $(20.0 \%)$.

The main blood proteins are albumin, globulins and fibrinogen. The latter promotes blood coagulation: turning into fibrin, it forms blood clots in the affected areas of the blood vessels and protects the body from blood loss. Between the content of albumin and globulin there is a ratio of their fractions. In this connection, the increased content of albumin and globulins in cows without pathology indicates a sufficient blood serum and fibrinogen, which apparently contributed to the normalization of the course of uterine involution and the postpartum period in our studies. A decrease in the blood serum of cows 25-30 days before calving of the total protein content by $21.9 \%$, an increase in the number of beta-globulins by $8.46 \%$ and that of gamma-globulins by $3.49 \%$ is consistent with studies by M.L.Kaker,
R.D. Myrray, H. Dobson [11] who noted that the thymus homogenate has an effect on the redistribution of protein fractions in the blood with an increased morphofunctional load on the animal organism.

According to the results of our studies, the content of GOT and GPT enzymes in animals with pathology of the course of labor and the postpartum period increased 25-30 days before delivery by $33.3 \%$ of the GOT enzyme and by $22.7 \%$ of the GPT enzyme, indicating the initial stage of hepatocyte dysfunction [20]. Our data are consistent with the literature that the GPT enzyme is contained mainly in the liver cells during its functional load and in case of damage to liver tissue cells are released into the bloodstream. In this connection, the level of this enzyme is used as an indicator of damage to liver tissue and its function. Metabolic disorders in highly productive cows lead to damage to liver cells and impaired filtration properties of the kidneys, which contributes to an increase in the level of GPT enzymes. An increase in serum aminotransferase activity begins 1520 days before the appearance of the main clinical signs of the disease and reaches its maximum value in the first days of the development of the pathological process $[1,2$, 16].

Characterizing the GOT enzyme, it should be noted that it is found in all cells of the body, but mainly in the cells of the heart, liver, and to a lesser extent in the kidneys and muscles. Normally, the level of GOT does not exceed 80 units/liter. When liver or muscle tissue is damaged, aspartate aminotransferase is released into the blood, which is a fairly accurate indicator of liver damage and cardiovascular system disorders.

A decrease in morphobiochemical blood parameters of cows 25-30 days before labor indicates a metabolic disorder in their body, as well as the symptomatic nature of the manifestation of birth and postpartum pathologies. The results of our studies are confirmed by indicators of the reproductive function of cows.

\section{Conclusion}

According to domestic and foreign researchers, pregnancy and subsequent labor, restoration of the reproduction function after calving in cows is accompanied by a change in metabolism up to hidden forms and manifestations. The metabolic state is characterized by blood counts. The course of labor and the postpartum period in cows depends on the dynamics of its changes. From the conducted experimental studies, it is seen that a decrease in the serum hemoglobin, leukocytes, total protein, alpha-globulins, calcium, glucose, alkaline reserve, immunoglobulins A, M, G with an increased content of beta-globulins and the enzymes GOT and GPT is a symptomatic factor of manifestations of labor and postpartum pathologies.

With the parameters of blood indicators in cows for 25-30 days before birth in the following values: 92.80 $\mathrm{g} / \mathrm{l}$ of hemoglobin, $57.17 \mathrm{~g} / \mathrm{l}$ of total protein, $36.43 \%$ of albumin, $1.78 \mathrm{mmol} / \mathrm{l}$ of calcium, $1.07 \mathrm{mmol} / \mathrm{l}$ of inorganic phosphorus, 38.85 vol \% CO2 of alkaline reserve, $1.88 \mathrm{mmol} / \mathrm{l}$ of glucose; $126.36 \mathrm{mg} / \mathrm{dl}$, 
$97.16 \mathrm{mg} / \mathrm{dl}$ and $1012.49 \mathrm{mg} / \mathrm{dl}$ and less of immunoglobulins A, M and G, respectively, and 124.29 units/1 of GPT enzymes and 104.49 units/l and more of GOT enzymes, the likelihood of manifestation of labor and postpartum pathologies increases, which suggests that it is possible to use the results of studies to develop an algorithm for predicting and preventing postpartum complications in highly productive cows.

\section{References}

1. D.A. Abylkasymov, L.V. Ionova, N.P. Sudarev, P.S. Kamynin, Dairy and beef cattle breed. 1, 9-11 (2014)

2. V.D. Kocharyan, G.S. Chizhova, M.A. Nikitina, Bull. of the Lower Volga Agricult. Univer., sci. and higher professional ed. 3, 1-4 (2012)

3. L.M. Chagas, J.J. Bass, D. Blacheet al., J. Dairy Sci. 90, 4022-4032 (2007)

4. H. Dobson, R.F. Smith, M.D. Royal, C.H. Knight, I.M. Sheldon, Reprod. Domest. Anim. 42(2), 17-23 (2007)

5. A.P. Kostin, Bull. of Agricult. Sci. 3, 18 (1990)

6. S.A. Chulichkova, Intellectual and scientific potential of the XXI century (Ufa, 2016)

7. O.A. Bykov, Feed. of agricult. animals and fooder product. 11, 46-49 (2014)
8. I.M. Donnik, O.P. Neverova, O.V. Gorelik, Proceed. of Kuban State Agrari.Univer. 56, 176-179 (2015)

9. M.A. Bagmanov, R.N. Mukhmetgaliev, Collection of scientific papers (Kazan, 2001)

10. O.A. Bykov, Agro-food policy in Russ. 3, 64-66 (2015)

11. M.L. Kaker, R.D. Murray, H. Dobson, Veter. Rec. 115, 378-382 (2004)

12. W. Novak, Med. Veter. 9, 1049-1051 (2005)

13. K.I. Minzhasov, V.D. Mukhametova, V.D. Aubakirova, Agricult., Forestry and Water Manag. 3 (2013)

14. I.V Nenashev, Sh.M. Bikteev, Bull. of the Orenburg State Agrar.Univer. 20-1, 183-185 (2008)

15. O.P. Neverova, I.M. Donnik, O.V. Gorelik, A.G. Koshchaev, Agrar. Bull. Urals 10, 35-39 (2015)

16. M.C. Lucy, Reproduct. in Domestic Ruminants 64, 237-254 (2007)

17. N. Martinez, C.A. Riso, F.S. Lima et al., J. Dairy Sci. 95, 7158-7172 (2012)

18. O.V. Kremnev, Problems and prospects for improving food products (Volgograd, 2002)

19. A.G. Nezhdanov, Veter. Med. 11, 50 (1982)

20. Yu.V. Zhuk, M.M. Mikhaylyuk, V.I. Lyubetskiy, Sci. notes VSAVM 2-2, 47-50 (2011) 